\title{
Application of Factorial Design on the Extraction of Green Tea Leaves (Camellia sinensis L.)
}

\author{
Eka Indra Setyawan ${ }^{1}$, Abdul Rohman², Erna Prawita Setyowati ${ }^{3}$, Akhmad Kharis Nugroho $^{4 *}$ \\ 'Departement of Pharmacy, Faculty of Mathematics and Natural Sciences, Udayana University, Bali, Indonesia. \\ ${ }^{2}$ Departement of Pharmaceutical Chemistry, Faculty of Pharmacy, Gadjah Mada University, Yogyakarta, Indonesia. \\ ${ }^{3}$ Departement of Pharmaceutical Biology, Faculty of Pharmacy, Gadjah Mada University, Yogyakarta, Indonesia. \\ ${ }^{4}$ Departement of Pharmaceutical Technology, Faculty of Pharmacy, Gadjah Mada University, Yogyakarta, Indonesia.
}

\section{ARTICLE INFO \\ Article history: \\ Received on: 13/01/2018 \\ Accepted on: 09/03/2018 \\ Available online: 29/04/2018}

\section{Key words:}

Factorial design,

optimization, green tea,

extraction.

\begin{abstract}
Green tea (Camellia sinensis L.) contains bioactive compounds such as epigallocatechin gallate (EGCG), caffeine, and gallic acid. The study aimed to optimize the extraction condition using the experimental design of factorial design. Two variables namely water temperature $\left(75\right.$ and $\left.95^{\circ} \mathrm{C}\right)$ and brewing number (one and two-times) were used and objected to factorial design in order to get the optimum condition. The determination of EGCC, caffeine, and gallic acid was carried out using high-performance liquid chromatography method equipped with the UV-visible detector. The result showed that the extraction yield varied from $4.48 \%-7.56 \%$. The level of EGCG and caffeine in green tea extract varied from $251.96-393.34 \mathrm{mg} / \mathrm{g}$ dry weight and $32.94-46.82 \mathrm{mg} / \mathrm{g}$ dry weight, while the level of gallic acid could not be quantified in each experiment because it was below the limit of quantification (LOQ). The predicted optimum extraction condition consisted of water temperature at $95^{\circ} \mathrm{C}$ with two-times brewing. Using this optimum condition, the concentrations of EGCG, caffeine and the extraction yield were of $356.43 \mathrm{mg} / \mathrm{g}$ dry weight, $38.76 \mathrm{mg} / \mathrm{g}$ dry weight, and $5.76 \%$, respectively.
\end{abstract}

\section{INTRODUCTION}

Green tea is manufactured by steaming and drying of Camellia sinensis L. Green tea is rich in polyphenols, and most of them are catechins (Michele et al., 2014). Catechins in green tea can be (+)-catechin (C), (-)-catechin 3-gallate (CG), (-)-epicatechin (EC), (-)-epicatechin 3-gallate (ECG), (-)-epigallocatechin (EGC), (-)-gallocatechin 3-gallate (GCG), (-)-gallocatechin (GC), and epigallocatechin 3-gallate (EGCG) (58-55\% of total polyphenols) (Fang et al., 2006; Michele et al., 2014; Perva-Uzunalić et al., 2006). EGCG is the most abundant and commonly used as biomarker compound. EGCG has been reported have antioxidant, antimutagenic, anticarcinogenic and antibacterial properties (Komes et al., 2010; Michele et al., 2014; Perva-Uzunalić et al., 2006).

\section{${ }^{*}$ Corresponding Author}

Prof. Dr. Akhmad Kharis Nugroho, M.Si., Apt., Departement of Pharmaceutical Technolgy, Faculty of Pharmacy, Gadjah Mada University, Yogyakarta, Indonesia.E-mail: a.k.nugroho@gmail.com
Other components such as caffeine (2.5-3.5\% of dry weight) (Michele et al., 2014), fats (16\%), triterpenoids, proteins, amino acids, sterols, vitamins, minerals were found in green tea (Perva-Uzunalić et al., 2006). Caffeine is related to diuretic responses and influences central nervous system activity. Higher dose ( $>200 \mathrm{mg} /$ day) of caffeine induces nervousness, headache, tremors, sleeplessness, increased blood pressure, etc. (Michele et al., 2014; Yang et al., 2007). Green tea also comprises a gallic acid, a yield of degradation generated from galloyled catechins (Khalaf et al., 2008).

Green tea is widely known as a traditional beverage (Yang et al., 2007; Venditti et al., 2010; Damiani et al., 2014; Michele et al., 2014). The method for preparing the beverage varies around the world. Chinese brew tea leaves in hot water (70$80^{\circ} \mathrm{C}$ ), and the brewing is done repeatedly seven-times. In Japan, green tea is prepared in hot water for two minutes and it can be used for two to three times. In Taiwan, it is brewed in cold water $\left(4\right.$ or $\left.25^{\circ} \mathrm{C}\right)$. Brewing tea in cold water provides lower levels of caffeine, reduces bitterness and creates more flavor (Venditti et al., 2010). Different techniques for preparing the beverage product lead to varied levels of green tea compounds (Lin et al., 2003). 
In recent years, many green tea leaf extractions have been developed including extraction of catechin, caffeine and gallic acid from tea bag infusions using different steeping method (Yang et al., 2007), extraction of major catechin and caffeine from green tea using different solvents (Perva-Uzunalić et al., 2006), solvent extraction of catechin from Korean tea (Row and Jin 2006), extraction of bioactive compounds from green tea using aqueous extraction (Komes et al., 2010). In addition, comparison of the hot and cold water extraction on the antioxidant activity has been reported (Venditti et al., 2010). The application of factorial design to optimize the extraction condition has been performed in previous studies such as optimization of subcritical water extraction of flavanols from green tea leaves (Ko et al., 2014) and optimization extraction of Syzygium cumini L. (Migliato et al., 2011). This method was chosen because it is more simple and efficient than other methods. To our best knowledge, there is no report related to the use of the experimental design of factorial design to optimize the extraction conditions of green tea extract.

Several methods have been used to establish the level of EGCG, caffeine and gallic acid from green tea. Previous studies were done using HPLC with UV-visible detector (Li et al., 2012; Row and Jin 2006; Rusak et al., 2008), high-liquid chromatography using diode array detector (Perva-Uzunalić et al., 2006), electrophoresis (Kotani et al., 2007), thin-layer chromatography (Vovk et al., 2005), fourier transform near infrared spectrometry (Chen et al., 2009b; Chen et al., 2009a), near infrared spectrometry (Chen et al., 2006), reflectance spectroscopy, centrifugal precipitation chromatography (Baldermann et al., 2009), potentiometric flow injection (Koutelidakis et al., 2009; Nieh et al., 2009), high-speed counter current chromatography (Kumar and Rajapaksha 2005; Yanagida et al., 2006).

In this study, high-liquid chromatography was chosen to establish the levels of EGCG, caffeine and gallic acid from green tea leaf extract. This method was able to provide data both qualitatively and quantitatively precisely and meticulously than other analysis methods. However, this method requires a relatively large cost (Sugihartini et al., 2014). The objective of this study was to determine the optimum extraction conditions such as water temperature and brewing number for the extraction of three primary compounds (EGCG, caffeine and gallic acid) and yields of extracts from green tea leaves.

\section{MATERIALS AND METHOD}

\section{Materials}

Green tea (Camellia sinensis L.) samples were obtained from Minangkabau, West Sumatera, Indonesia and they were determined by The Indonesian Institute of Science, Candi Kuning, Bali, Indonesia (No. B-450/IPH.7/AP/VI/2017). The reference standard of (-)-epigallocatechin gallate 80\% (E4268), caffeine (Y0000787), gallic acid 98\% (91215) were obtained from Aldrich (Sigma-Aldrich, Singapore). All the solvents utilized for analytical and extraction process were obtained from E. Merck (Darmstadt, Germany).

\section{Instrumentation and software}

HPLC system that was used consisted of Knauer HPLC Germany Smart-Line series with UV detector (Smart-Line UV detector 2500 A5140), Smart-Line pump 1000 V7603, $20 \mu \mathrm{L}$ Rheodyn Loop A135 sample injector, Eurosphere C-18 column $(250 \times 4.6 \mathrm{~mm}$, i.d $5 \mu \mathrm{m})$. Data were further analyzed using Chromgate software version 3.1. The water contents in green tea extract were determined by Ohaus Moisture MB 25. Design of Experiments (DoE) was performed using Design-Experts ${ }^{\circledR}$ software (Ver. 7.1.5: Stat-Ease Inc. Minneapolis, MN, USA).

\section{Validation of HPLC analysis}

Before the validation of HPLC, the system suitability test was performed by injecting a standard solution mixture of 20 $\mu \mathrm{L}$ with a concentration of $1 \mathrm{mg} / \mathrm{mL}$ (Martono and Martono 2013). The results of the system suitability test can be seen in Table 1. The validation of HPLC method was performed by assessing several parameters such as selectivity, linearity and range, limit of detection (LOD), limit of quantification (LOQ), accuracy, and precision (Prabaningdyah et al., 2017).

\section{Preparation of tea infusion}

The preparation of green tea extract was carried in single step extraction, and multiple step extraction. In the single step extraction, green tea samples (10 g) (Demir et al., 2015) were extracted in $250 \mathrm{~mL}$ hot water $\left(75\right.$ and $\left.95^{\circ} \mathrm{C}\right)$ for 20 minutes. The extract solution was cooled in cold water for $10 \mathrm{~min}$ and was fractionated with $100 \mathrm{~mL}$ ethyl acetate. The solvent was evaporated using a water bath and the yield of the extract was accurately weighed. This procedure was replicated three-times in each experiment. During the multiple step extraction, green tea samples $(10 \mathrm{~g})$ were extracted two-times under the same conditions as in the single step extraction in $150 \mathrm{~mL}$ hot water and continued in $100 \mathrm{~mL}$ hot water.

\section{Sample preparation of HPLC}

Green tea extracts $(10 \mathrm{mg})$ were diluted in mobile phase $(10 \mathrm{~mL})$ and sonicated (Krisbow DSA50-GL2-2.5L) for 15 minutes. The temperature was arranged at $30^{\circ} \mathrm{C}$. The mixture was then filtered using nylon membrane $(0.45 \mu \mathrm{m})$ and injected $(20 \mu \mathrm{L})$ into a port injector. It was replicated three times for each sample. The chromatographic separations were performed on Eurosphere C-18 column $(250 \times 4.6 \mathrm{~mm}$, i.d $5 \mu \mathrm{m})$. Mobile phase used was $0.1 \%$ orthophosphoric acid: water: acetonitrile: methanol $(14 ; 7 ; 3 ; 1 \mathrm{v} / \mathrm{v} / \mathrm{v} / \mathrm{v})$ at $\mathrm{pH} 4.00$ delivered isocratically with a flow rate of $1.2 \mathrm{~mL} / \mathrm{min}$. Analytes were detected using UV-visible detector at a wavelength of $280 \mathrm{~nm}$. The temperature was set at room temperature (Martono and Martono 2013; Sugihartini et al., 2014). The determination of the level of the compounds was performed by plotting the Area Under Curve (AUC) of each compound (EGCG, caffeine and, gallic acid) chromatogram with the regression of standard curve (Martono and Martono 2013; Proyong et al., 2007; Saito et al., 2006).

\section{Experimental design of extraction}

Factorial design (2-levels, 2-factors) was applied to determine the optimal condition of water temperature and brewing number to extract the green tea compounds. Water temperature (A) and brewing number (B) were independent variables studied to optimize the response (Y) such as the yield of extract $\left(\mathrm{Y}_{1}\right)$ and levels of EGCG $\left(\mathrm{Y}_{2}\right), \mathrm{CAF}\left(\mathrm{Y}_{3}\right)$, and 
GA $\left(\mathrm{Y}_{4}\right)$. The water temperatures varied at 75 and $95^{\circ} \mathrm{C}$ and the number of brewing at one and two-times. The factorial design (full factorial) requires an experiment number according to the following equation (Politis et al., 2017; Yu et al., 2014):

Number of experiments $=$ Levels $^{\text {factors }}$

Table 1: System suitability test results.

\begin{tabular}{|c|c|c|c|c|c|}
\hline \multicolumn{6}{|c|}{ Gallic acid } \\
\hline Replication & tR (min) & Asymetry USP & Width USP & Plates USP & HETP USP \\
\hline 1 & 3.33 & 1.210 & 0.28 & 15042.98 & 3761 \\
\hline 2 & 3.48 & 1.210 & 0.22 & 14795.00 & 3699 \\
\hline 3 & 3.41 & 1.150 & 0.22 & 15280.91 & 3820 \\
\hline Mean & 3.41 & 1.19 & 0.24 & 15039.63 & 3760.00 \\
\hline SD & 0.08 & 0.03 & 0.03 & 242.97 & 60.51 \\
\hline$\%$ RSD & 0.02 & 0.03 & 0.14 & 0.02 & 0.02 \\
\hline \multicolumn{6}{|c|}{ Caffeine } \\
\hline Replication & tR (min) & Asymetry USP & Width USP & Plates USP & HETP USP \\
\hline 1 & 12.25 & 0.924 & 0.52 & 21900.00 & 5475 \\
\hline 2 & 12.68 & 0.997 & 0.67 & 21648.00 & 5412 \\
\hline 3 & 12.80 & 0.990 & 0.67 & 22431.69 & 5608 \\
\hline Mean & 12.58 & 0.97 & 0.62 & 21993.23 & 5498.33 \\
\hline SD & 0.29 & 0.04 & 0.09 & 400.08 & 100.06 \\
\hline$\%$ RSD & 0.02 & 0.04 & 0.14 & 0.02 & 0.02 \\
\hline \multicolumn{6}{|c|}{ EGCG } \\
\hline Replication & tR (min) & Asymetry USP & Width USP & Plates USP & HETP USP \\
\hline 1 & 17.70 & 1.082 & 1.05 & 16406.03 & 4102 \\
\hline 2 & 17.80 & 1.071 & 1.06 & 16618.00 & 4155 \\
\hline 3 & 17.90 & 1.065 & 1.07 & 17395.34 & 4349 \\
\hline Mean & 17.80 & 1.07 & 1.06 & 16806.46 & 4202.00 \\
\hline SD & 0.10 & 0.01 & 0.01 & 520.89 & 130.03 \\
\hline$\%$ RSD & 0.01 & 0.01 & 0.01 & 0.03 & 0.03 \\
\hline
\end{tabular}

For example, a full factorial of three factors requires $2^{2}=4$ experiments and when it is replicated three times, it will generate 12 experiments to run. The response was estimated by the following factorial equation (Çelik 2017):

$$
\mathrm{Y}=\beta_{0}+\beta_{1} \mathrm{~A}+\beta_{2} \mathrm{~B}+\beta_{12} \mathrm{AB}+\varepsilon
$$

Wherein, $\mathrm{Y}$ is the estimated response, $\mathrm{A}$ and $\mathrm{B}$ indicate the independent variables, $\beta_{0}$ is the intercept value, $\beta_{1}$ and $\beta_{2}$ are linear coefficients, while $\beta_{11}$ and $\beta_{22}$ are the factorial coefficient (Çelik 2017; Pramod et al., 2016; Yu et al., 2014). Analysis of Variance (ANOVA) was used to evaluate the effect of independent variables on the response. The optimized conditions were prepared and compared with the predicted values.

\section{RESULTS AND DISCUSSION}

\section{Validation method}

During the system suitability test, the percent of the relative standard deviation ( $\% \mathrm{RSD})$ of the retention time was evaluated. The result showed RSD values of $0.02 \%, 0.02 \%$, and $0.01 \%$ for the retention time of gallic acid, caffeine, and EGCG, indicating the suitability of HPLC system $(\mathrm{RSD}<2 \%)$. The numbers of theoretical plates (N) and Height Equivalent of A Theoretical Plate (HETP) for the three replicate injections were found about 15039.63 and
3760 for gallic acid, 21993.23 and 5498.33 for caffeine as well as, 16806.46 and 4202 for EGCG, indicating the acceptable criteria for parameters of $\mathrm{N}(>2000)$ and HETP.

\section{Selectivity}

A standard solution mixture of gallic acid, caffeine, and EGCG at a concentration of $1 \mathrm{mg} / \mathrm{mL}$, respectively was prepared by diluting into a mobile phase and $20 \mu \mathrm{L}$ of it was injected into an HPLC system. Resolution (Rs) value obtained was 21.32 for the gallic acid and caffeine and 6.22 for the caffeine and EGCG indicating that HPLC is selective enough for analysis of gallic acid, caffeine, and EGCG ( Rs > 2). The HPLC chromatogram of gallic acid, caffeine, EGCG, and green tea extract is shown in Figure 1.

\section{Linearity and range}

The linearity of gallic acid, caffeine, and EGCG was evaluated from coefficient correlation (r-value) and intercept of the linear regression describing the relationship between the concentration of analytes (x-axis) and peak area (y). The concentration ranges used were $10-60 \mu \mathrm{g} / \mathrm{mL}$ for gallic acid, 1-25 $\mu \mathrm{g} / \mathrm{mL}$ for caffeine, and 5-50 $\mu \mathrm{g} / \mathrm{mL}$ for EGCG. The results showed a good relationship with an R-value of gallic acid, caffeine, and EGCG of $0.999,0.996$, and 0.998 , respectively. 


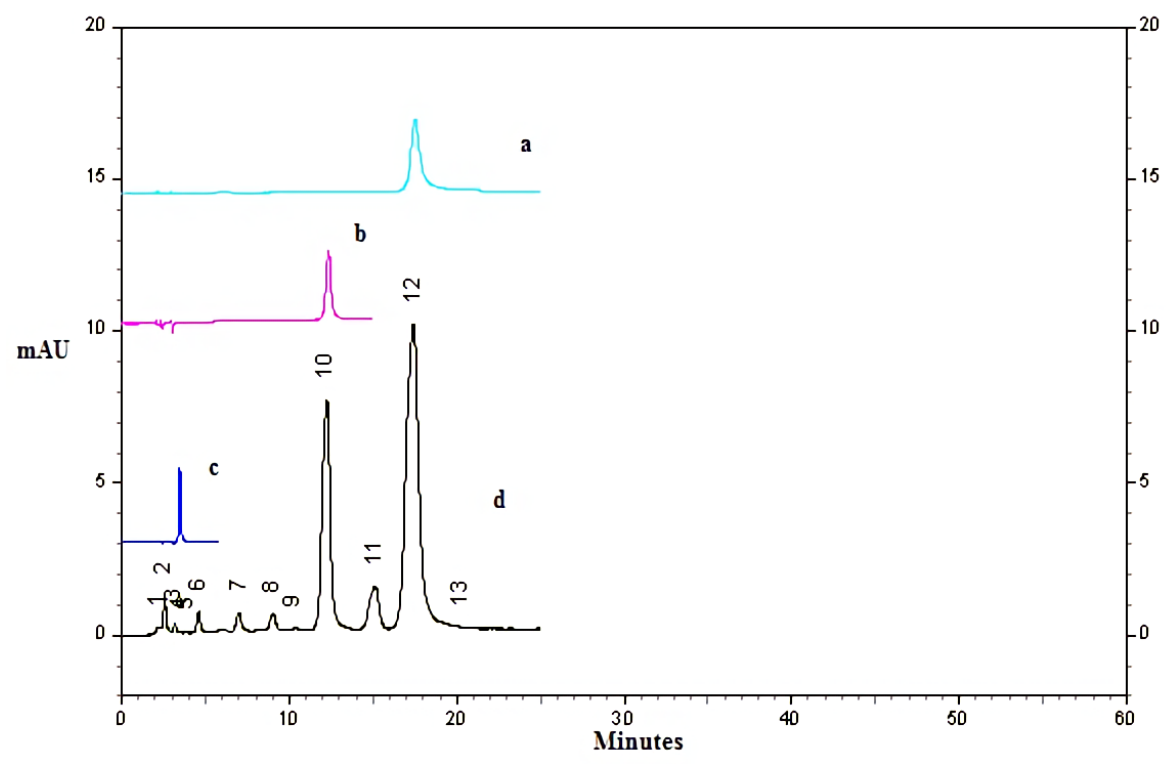

Fig. 1: HPLC chromatogram of EGCG standard (a), caffeine standard (b), gallic acid standard (c) and green tea extract (d).

Table 2: The linear regression equations and validation method of the EGCG, caffeine and gallic acid.

\begin{tabular}{|c|c|c|c|c|c|c|c|}
\hline \multirow{2}{*}{ Compound } & \multicolumn{7}{|c|}{ UV $280 \mathrm{~nm}$} \\
\hline & Linear range (ug/mg) & Linear regression equation & Linearity $\left(r^{2}\right)$ & LOD (ug/mL) & LOQ (ug/mL) & Accuracy (\% recovery) & Precision (\%RSD) \\
\hline EGCG & $5-50$ & $\mathrm{y}=21254 \mathrm{x}-111.9$ & 0.998 & 1.07 & 3.57 & $98.2-101.8$ & $1-2$ \\
\hline Caffeine & $1-25$ & $y=43688 x+63740$ & 0.996 & 1.72 & 1.72 & $98.5-102$ & $1.2-1.75$ \\
\hline Gallic acid & $10-60$ & $y=41800 x+14517$ & 0.999 & 3.8 & 12.8 & $98-102.2$ & $1.2-2$ \\
\hline
\end{tabular}

LOD and LOQ were calculated by using the equations below:

$$
\mathrm{LOD}=\frac{3.3 \times \mathrm{Sy} / \mathrm{x}}{\mathrm{b}^{-}} \mathrm{LOQ}=\frac{10 \times \mathrm{Sy} / \mathrm{x}}{\mathrm{b}}, \mathrm{Sy} / \mathrm{x}=\sqrt{\frac{\sum(\mathrm{yi}-\mathrm{yc}) 2}{\mathrm{n}=2}}
$$

Where LOD and LOQ values are $3.8 \mu \mathrm{g} / \mathrm{mL}$ and 12.8 for gallic acid, $0.52 \mu \mathrm{g} / \mathrm{mL}$ and $1.72 \mu \mathrm{g} / \mathrm{mL}$ for caffeine, and $1.07 \mu \mathrm{g} / \mathrm{mL}$ and $3.57 \mu \mathrm{g} / \mathrm{mL}$ for EGCG.

\section{Precision and accuracy}

The precision test was determined by repeatability test (intra-day precision) by analysis of three replicates of standard solution at concentration levels of 40,50 , and $60 \mu \mathrm{g} / \mathrm{mL}$ for gallic acid, 15,20 , and $25 \mu \mathrm{g} / \mathrm{mL}$ for caffeine as well as, 30, 40, and 50 $\mu \mathrm{g} / \mathrm{mL}$ for EGCG. The results showed the RSD values of gallic acid, caffeine, and EGCG were to be less than $2 \%$ (Table 2).

Recovery test was used to test the accuracy of the method. It was carried out at three different concentrations and repeated three times. The concentration of each standard solution was the same as that used in the precision test. The results showed that the $\%$ recovery of each compound was in the range of $98-102 \%$ (Table 2).

\section{Optimization of experimental design}

The DoE was adopted on the basis coded level from two variables (Table 3 ). The matrix of experimental design and response values are shown in Table 4 . The selected factors such as water temperature (in ${ }^{\circ} \mathrm{C}$ ) and brewing number were considered to have an influence on the experimental responses. The experiments obtained the levels of extraction yield varied from $4.48 \%$ to $7.56 \%$, EGCG levels that varied from $251.96 \mathrm{mg} / \mathrm{g}$ dry weight to $393.34 \mathrm{mg} / \mathrm{g}$ dry extract, caffeine levels varied from $32.94 \mathrm{mg} / \mathrm{g}$ dry extract to $39.17 \mathrm{mg} / \mathrm{g}$ dry extract, meanwhile gallic acid level was not quantified or not detected in each experiment. Therefore, this study only used three responses for further analysis.

The effect of the extraction conditions on the yield extraction $\left(\mathrm{Y}_{1}\right)$ can be illustrated by the following equation:

$$
\mathrm{Y}_{1}=5.67+0.80(\mathrm{~A})-0.36(\mathrm{~B})-0.27(\mathrm{~A})(\mathrm{B})
$$

The statistical results showed that the adjusted coefficient of determination (Adj. $\left.\mathrm{R}^{2}\right)$ generated was $0.8675\left(\mathrm{R}^{2}>0.8\right)$. It indicates that the equation model is the best fit using this equation (Prabaningdyah et al., 2017). The relationship between equation model and observation data of extraction yield is shown in Figure $2 \mathrm{a}$. The variables of $\mathrm{A}, \mathrm{B}$, and the interaction between $\mathrm{A}$ and $\mathrm{B}$ contributed significantly to the response of $Y_{1}$ ( $p$-value $<0.05$ ). The equation model showed that the water temperature had a positive effect on the extraction yield indicating that with an increasing water temperature, yield extraction increases. It is due to the cell wall of green tea leaves that become more permeable to the solvent and the solubility and diffusion coefficient of the constituents increase (Vuong et al., 2011b; Vuong et al., 2011a; Vuong et al., 2010). 
a

Design-Expert@ Software Yield

$\Delta$ Error from replicates

A: Water temp,

B: Brewing

- Positive Effects

- Negative Effects

b

Design-Expert@ Software EGCG

$\Delta$ Error from replicates

A: Water temp,

B: Brewing

口 Positive Effects

- Negative Effects

C

Design-Expert $\circledast$ Software

Caffeine

$\Delta$ Error from replicates

A: Water temp,

$B$ : Brewing

$\square$ Positive Effects

घ Negative Effects

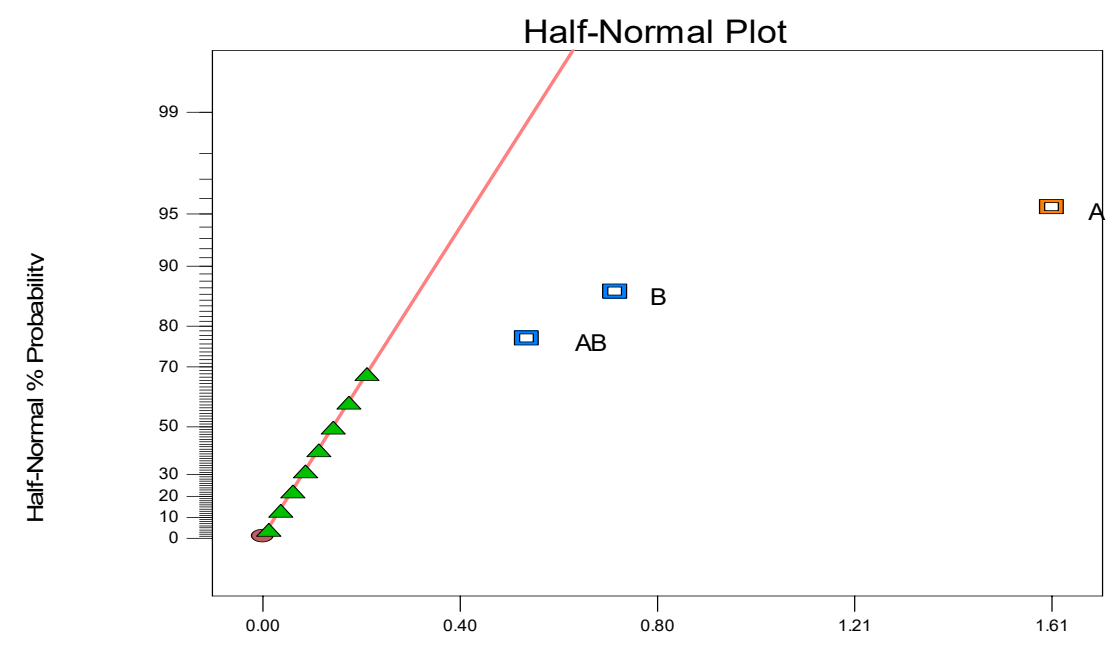

|Standardized Effect|
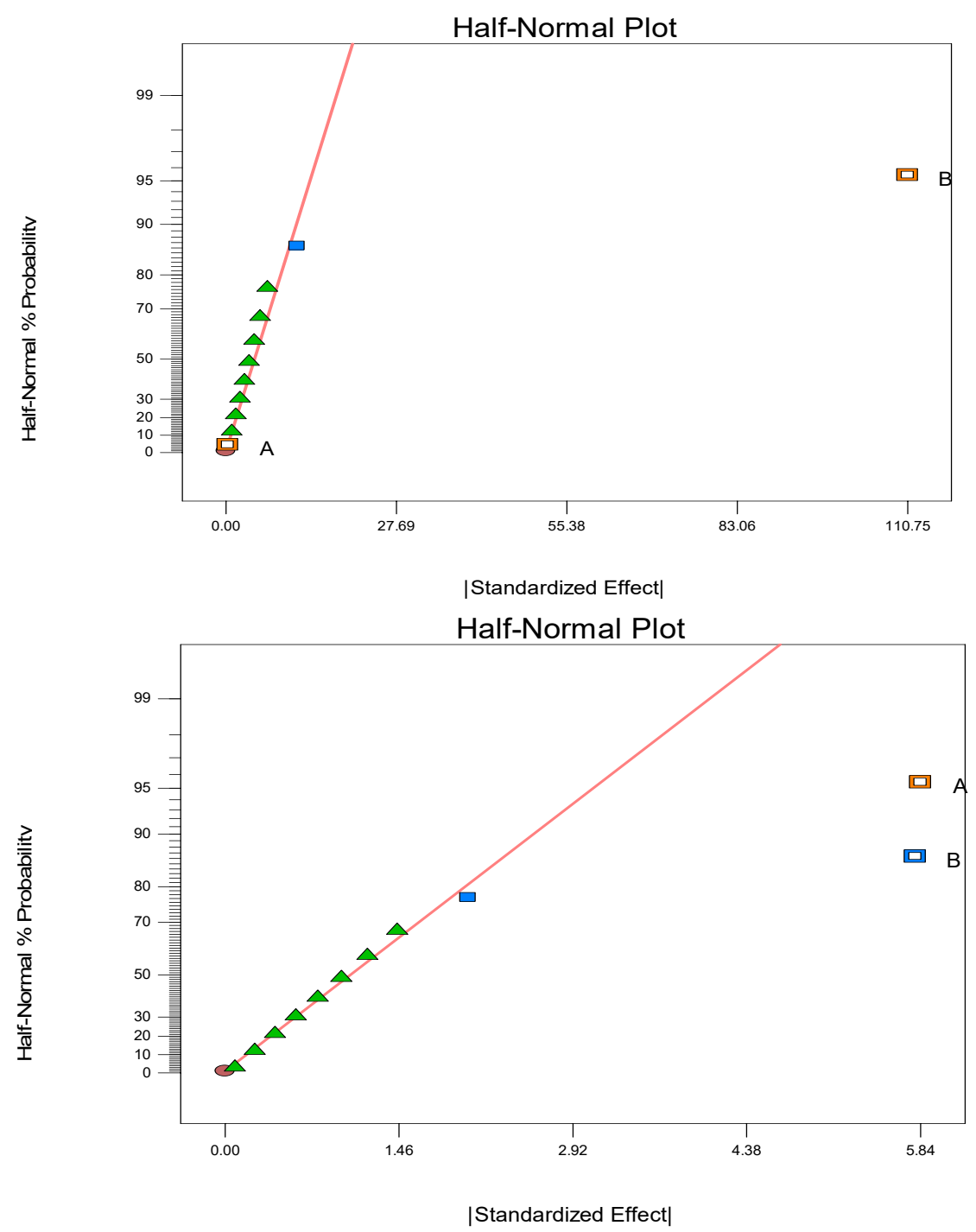

Fig. 2: The relationship between observation results of extraction yield on the selected model graph (a), the relationship between observation results of EGCG Level on the selected model (b), the relationship between observation results of caffeine level on the selected model (c). 
Table 3: The codes and uncoded levels of independent variables used in the factorial design.

\begin{tabular}{cccc}
\hline \multirow{2}{*}{ Independent variables } & \multirow{2}{*}{ Symbol } & \multicolumn{2}{c}{ Levels } \\
\cline { 3 - 4 } & & Low (-1) & High $(+\mathbf{1})$ \\
\hline Water temperature $\left({ }^{\circ} \mathrm{C}\right)$ & $\mathrm{A}$ & 75 & 95 \\
Brewing number & $\mathrm{B}$ & One-time & Two-times \\
\hline
\end{tabular}

The effect of the extraction conditions on the EGCG level $\left(\mathrm{Y}_{2}\right)$ can be illustrated by the following equation:

$$
\mathrm{Y}_{2}=314.84+55.38(\mathrm{~B})
$$

The statistical results showed that the adjusted coefficient of determination (Adj. $\mathrm{R}^{2}$ ) generated was $0.9669\left(\mathrm{R}^{2}>0.8\right)$. It indicates that the equation model is the best fit using this equation. The relationship between equation model and observation data of EGCG levels is shown in Figure 2b. Only variable B contributed significantly to the response of $Y_{2}$ (p-value $<0.05$ ). The equation model showed that only brewing number had a positive effect on the EGCG level. It indicates that with an increasing brewing number, EGCG level increases. In the first infusion, EGCG did not release entirely. They would release entirely during to the next infusion (Yang et al., 2007). The water temperature contributed insignificantly to the EGCG level. In this case, that the temperature exceeding $75^{\circ} \mathrm{C}$ for 20 minutes may affect the stability of EGCG and it did not significantly differ (p-value of 0.9565 ). The extraction temperature above $80^{\circ} \mathrm{C}$ could induce an increased epimerization reaction.

Table 4: The experimental design of extraction conditions using 22 factorial design.

\begin{tabular}{|c|c|c|c|c|c|c|c|}
\hline \multirow{2}{*}{ Std } & \multirow{2}{*}{ Run } & Factor $1(A)$ & Factor 2 (B) & Response $1\left(Y_{1}\right)$ & Response $2\left(\mathrm{Y}_{2}\right)$ & Response $3\left(\mathrm{Y}_{3}\right)$ & Response $4\left(\mathrm{Y}_{4}\right)$ \\
\hline & & Water temperature $\left({ }^{\circ} \mathrm{C}\right)$ & Brewing number & Yield extraction (\%) & EGCG (mg/g dry weight) & Caffeine (mg/g dry weight) & Gallic acid ( $\mathrm{mg} / \mathrm{g}$ dry weight) \\
\hline 1 & 9 & 75 & 1 & 4.64 & 251.96 & 44.07 & Under LOQ \\
\hline 2 & 4 & 75 & 1 & 5.36 & 256.08 & 35.71 & Under LOD \\
\hline 3 & 8 & 75 & 1 & 4.86 & 252.53 & 36.31 & Under LOD \\
\hline 4 & 2 & 95 & 1 & 6.89 & 266.55 & 46.82 & Under LOQ \\
\hline 6 & 6 & 95 & 1 & 7.56 & 264.37 & 46.48 & Under LOQ \\
\hline 7 & 3 & 75 & 2 & 4.78 & 365.61 & 32.94 & Under LOQ \\
\hline 8 & 11 & 75 & 2 & 4.96 & 368.53 & 36.18 & Under LOQ \\
\hline 9 & 12 & 75 & 2 & 4.58 & 393.34 & 35.70 & Under LOQ \\
\hline 10 & 5 & 95 & 2 & 6.36 & 367.80 & 38.13 & Under LOQ \\
\hline
\end{tabular}

The effect of the extraction conditions on the caffeine level $\left(\mathrm{Y}_{3}\right)$ can be illustrated by the following equation:

$$
\mathrm{Y}_{3}=3.974+2.92(\mathrm{~A})-2.90(\mathrm{~B})
$$

The statistical results showed that the adjusted coefficient of determination $\left(\right.$ Adj. $\left.\mathrm{R}^{2}\right)$ generated was $0.7115\left(\mathrm{R}^{2}<0.8\right)$. Although the value of adjusted coefficient determination was less than 0.8 , lack of fit $\mathrm{p}$-value showed insignificant value ( $\mathrm{p}$-value $>$ $0.05)$. Lack of fit illustrates the variation of the data around the fitted model. If the model is not best to fit the data, this will be significant. The relationship between equation model and observation data of caffeine levels is shown in Figure 2c. Variables $\mathrm{A}$ and $\mathrm{B}$ significantly contributed to the response of $\mathrm{Y}_{3}$ ( $\mathrm{p}$-value $<0.05)$. The equation model showed that water temperature had a positive effect on the caffeine level. It indicates that with an increasing water temperature, caffeine level increases. Increased caffeine level at a higher temperature is caused by an increased solubility of caffeine. In contrast to the brewing number, it had a negative effect on the caffeine level, indicating that with an increasing brewing number, caffeine level decreases. It is due to the saturation of extraction.

The optimization process was carried out by determining the criteria of each response such as the maximum level of the extraction yield, maximum level on the EGCG and minimum level on the caffeine. The assessment was made upon consideration that EGCG is the main compound contained in the extract of green tea leaf that potentially has a biological activity, whereas caffeine is not a biomarker compound that will mask the biological activity of EGCG in this case. The extraction yield was a significant factor in the preparation of pharmaceutical dosage form and it was used as raw material. The optimum extraction conditions were to use water temperature at $95^{\circ} \mathrm{C}$ with two-times brewing obtaining these extraction yields, EGCG and caffeine level of $5.76 \%, 356.43 \mathrm{mg} / \mathrm{g}$ dry weight, and $38.76 \mathrm{mg} / \mathrm{g}$ dry weight, respectively. There was no significant difference ( $\mathrm{p}$-value of extraction yield, EGCG, caffeine level of $0.787 ; 0.167 ; 0.077$, respectively) between the observation results and prediction values. The model predicted extraction yields, EGCG and caffeine levels of $5.84 \%, 370.39 \mathrm{mg} / \mathrm{g}$ dry weight, and $39.76 \mathrm{mg} / \mathrm{g}$ dry weight, respectively. The model obtained a desirability value of 0.67 , illustrating that the model is close to the observation results. Desirability value ranged from 0 to 1 , illustrating a relationship between the observation results and the model predicted. The effect of the optimum extraction conditions on the desirability value can be seen in Figure 3. 
Design-Expert@ Software

Desirability

- Design Points

- B1 1 times

$\Delta$ B2 2 times

$\mathrm{X} 1=\mathrm{A}:$ Water temp,

$\mathrm{X} 2=\mathrm{B}$ : Brewing

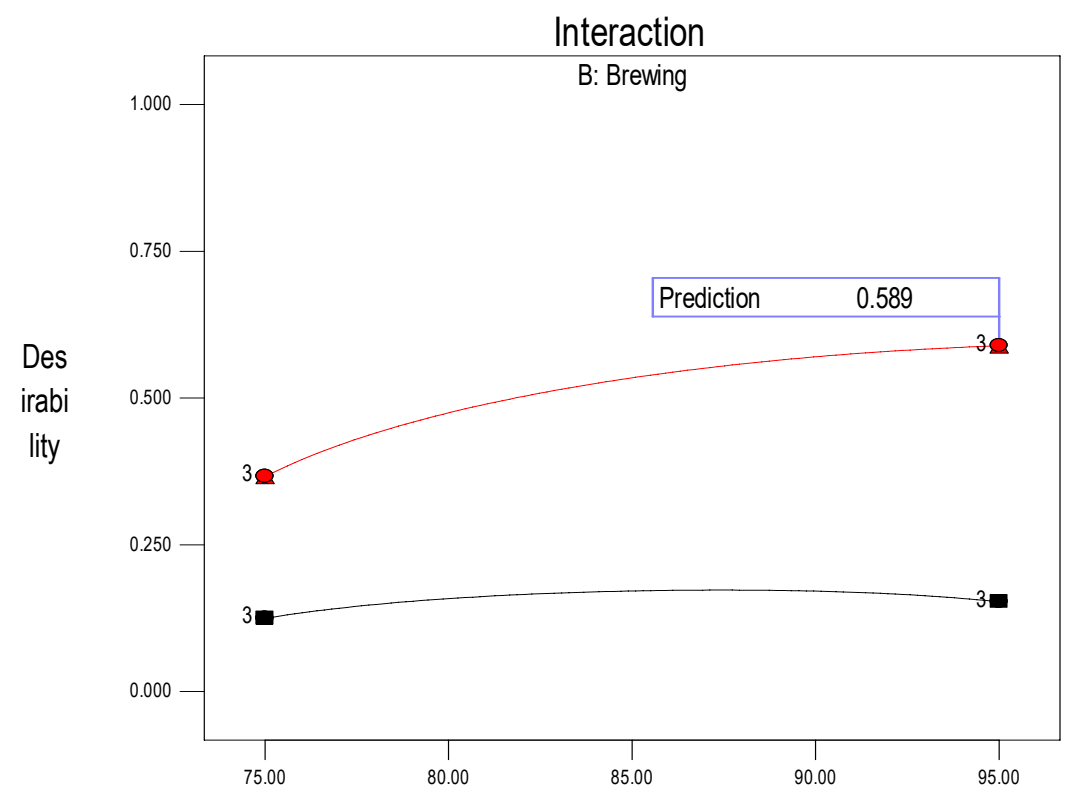

A: Water temp,

Fig. 3: The effect of optimum extraction conditions on the desirability value.

\section{CONCLUSION}

The factorial design has been used successfully to optimize the extraction condition of green tea leaves. Extraction process using water temperature at $95^{\circ} \mathrm{C}$ with two-times brewing is the optimum conditions to obtain the extraction yield, EGCG, and caffeine. Using this optimum condition, the concentrations of EGCG, caffeine and the extraction yield are of $356.43 \mathrm{mg} / \mathrm{g}$ dry weight, $38.76 \mathrm{mg} / \mathrm{g}$ dry weight, and $5.76 \%$, respectively.

\section{ACKNOWLEDGMENT}

This research was supported by Lembaga Pengelola Dana Pendidikan (LPDP) and Beasiswa Unggulan Dosen Indonesia-Dalam Negeri (BUDI-DN).

\section{CONFLICT OF INTEREST}

The author declares there is no conflict of interest.

\section{REFERENCES}

Baldermann S, Fleischmann P, Bolten M, Watanabe N, Winterhalter P, Ito Y. Centrifugal precipitation chromatography, a powerful technique for the isolation of active enzymes from tea leaves (Camellia sinensis). J. Chromatogr. A., 2009; 1216:4263-7.

Çelik B. Risperidone mucoadhesive buccal tablets: formulation design, optimization and evaluation. Drug Des. Devel. Ther., 2017; 11:3355-65.

Chen Q, Zhao J, Chaitep S, Guo Z. Simultaneous analysis of main catechins contents in green tea (Camellia sinensis (L.)) by Fourier transform near-infrared reflectance (FT-NIR) spectroscopy. Food Chem., 2009a; 113:1272-7.

Chen Q, Zhao J, Lin H. Study on discrimination of Roast green tea (Camellia sinensis L.) according to geographical origin by FT-NIR spectroscopy and supervised pattern recognition. Spectrochim. Acta. A. Mol. Biomol. Spectrosc., 2009b; 72:845-50.

Chen Q, Zhao J, Zhang H, Wang X. Feasibility study on qualitative and quantitative analysis in tea by near-infrared spectroscopy with multivariate calibration. Anal. Chim. Acta., 2006; 572:77-84.

Damiani E, Bacchetti T, Padella L, Tiano L, Carloni P. Antioxidant activity of different white teas: Comparison of hot and cold tea infusions. J. Food Compos. Anal., 2014; 33:59-66.

Demir E, Serdar G, Sökmen M. Comparison of some extraction methods for isolation of catechins and caffeine from Turkish green tea. Int. J. Second. Metab., 2015; 2:16-25.

Fang JY, Hwang TL, Huang YL, Fang CL. Enhancement of the transdermal delivery of catechins by liposomes incorporating anionic surfactants and ethanol. Int. J. Pharm., 2006; 310:131-8.

Khalaf NA, Shakya AK, Al-Othman A, El-Agbar Z, Farah H. Antioxidant activity of some common plants. Turkish J. Biol., 2008; 32:515 .

Ko M-J, Cheigh C-I, Chung M-S. Optimization of subcritical water extraction of flavanols from green tea leaves. J. Agric. Food Chem. 2014; 62:6828-33.

Komes D, Horžić D, Belščak A, Ganić KK, Vulić I. Green tea preparation and its influence on the content of bioactive compounds. Food Res. Int., 2010; 43:167-76.

Kotani A, Takahashi K, Hakamata H, Kojima S, Kusu F. Attomole catechins determination by capillary liquid chromatography with electrochemical detection. Anal. Sci., 2007; 23:157-63.

Koutelidakis AE, Argiri K, Serafini M, Proestos C, Komaitis $\mathrm{M}$, Pecorari M, et al. Green tea, white tea, and Pelargonium purpureum increase the antioxidant capacity of plasma and some organs in mice. Nutrition., 2009; 25:453-8.

Kumar NS, Rajapaksha M. Separation of catechin constituents from five tea cultivars using high-speed counter-current chromatography. J. Chromatogr. A., 2005; 1083:223-8.

Li D, Martini N, Wu Z, Wen J. Development of an isocratic HPLC method for catechin quantification and its application to formulation studies. Fitoterapia., 2012; 83:1267-74.

Lin Y-S, Tsai Y-J, Tsay J-S, Lin J-K. Factors affecting the levels of tea polyphenols and caffeine in tea leaves. J. Agric. Food Chem., 2003; $51: 1864-73$.

Martono Y, Martono S. High-performance liquid chromatography analysis for determination of gallic acid, caffeine, and epigallocatechin gallate concentration in various tea bags product. Agritech., 2013; 32:362-9. 
Michele CA, Priscila A de A, Hudson CP, Nadia RBR, Anderson de Oliviera F, Marcos AFB. Green tea in transdermal formulation: HPLC method for quality control and in vitro drug release assay. Quim. Nov., 2014; 37:1699-706.

Migliato KF, Corrêa MA, Salgado HRN, Tognolli JO, Sacramento LVS, Mello JCP de, et al. Factorial design optimization extraction of syzygium cumini L. Quim. Nova., 2011; 34:695-9.

N. Politis S, Colombo P, Colombo G, M. Rekkas D. Design of experiments (DoE) in pharmaceutical development. Drug Dev. Ind. Pharm., 2017;43: 889-901.

Nieh C-H, Hsieh B-C, Chen P-C, Hsiao H-Y, Cheng T-J, Chen RLC. Potentiometric flow-injection estimation of tea fermentation degree. Sensors Actuators B Chem., 2009; 136:541-5.

Perva-Uzunalić A, Škerget M, Knez Ž, Weinreich B, Otto F, Grüner S. Extraction of active ingredients from green tea (Camellia sinensis): Extraction efficiency of major catechins and caffeine. Food Chem., 2006; 96:597-605.

Prabaningdyah NK, Riyanto S, Rohman A, Siregar C. Application of HPLC and response surface methodology for simultaneous determination of curcumin and desmethoxy curcumin in Curcuma syrup formulation. J. Appl. Pharm. Sci., 2017; 7:58-64.

Pramod K, Tahir Ma, Charoo N, Ansari S, Ali J. Pharmaceutical product development: A quality by design approach. Int. J. Pharm. Investig., 2016; 6:129-38.

Proyong P, Weerapreeyakul N, Sripanidkulchai B. Validation of isocratic eluting and stepwise flow rate gradient for HPLC determination of cateohins, gallic acid and caffeine in tea. ScienceAsia., 2007; 33:113-7.

Row KH, Jin Y. Recovery of catechin compounds from Korean tea by solvent extraction. Bioresour. Technol., 2006; 97:790-3.

Rusak G, Komes D, Likić S, Horžić D, Kovač M. Phenolic content and antioxidative capacity of green and white tea extracts depending on extraction conditions and the solvent used. Food Chem., 2008; 110:852-8.

Saito ST, Welzel A, Suyenaga ES, Bueno F. A method for fast determination of epigallocatechin gallate (EGCG), epicatechin (EC), catechin $(C)$ and caffeine (CAF) in green tea using HPLC. Ciência e Tecnol. Aliment., 2006; 26:394-400.
Sugihartini N, Fudholi A, Pramono S, Sismindari S. Validation method of quantitative analysis of epigallocatechin gallate by highperformance liquid chromatography. Pharmaciana., 2014; 4:111-5.

Venditti E, Bacchetti T, Tiano L, Carloni P, Greci L, Damiani E. Hot vs. cold water steeping of different teas: Do they affect antioxidant activity? Food Chem., 2010; 119:1597-604.

Vovk I, Simonovska B, Vuorela H. Separation of eight selected flavan-3-ols on cellulose thin-layer chromatographic plates. J. Chromatogr. A., 2005; 1077:188-94.

Vuong QV, Golding JB, Nguyen M, Roach PD. Extraction and isolation of catechins from tea. J. Sep. Sci., 2010; 33:3415-28.

Vuong QV, Golding JB, Stathopoulos CE, Nguyen MH, Roach PD. Optimizing conditions for the extraction of catechins from green tea using hot water. J. Sep. Sci., 2011a; 34:3099-106.

Vuong QV, Stathopoulos CE, Nguyen MH, Golding JB, Roach PD. Isolation of Green Tea Catechins and Their Utilization in the Food Industry. Food Rev. Int., 2011b; 27:227-47.

Yanagida A, Shoji A, Shibusawa Y, Shindo H, Tagashira M, Ikeda $\mathrm{M}$, et al. Analytical separation of tea catechins and food-related polyphenols by high-speed counter-current chromatography. J. Chromatogr. A., 2006; 1112:195-201.

Yang DJ, Hwang LS, Lin JT. Effects of different steeping methods and storage on caffeine, catechins and gallic acid in bag tea infusions. J. Chromatogr. A., 2007; 1156:312-20.

Yu LX, Amidon G, Khan MA, Hoag SW, Polli J, Raju GK, et al. Understanding pharmaceutical quality by design. AAPS J., 2014; 16:771-83.

How to cite this article:

Setyawan EI, Rohman A, Setyowati EP, Nugroho AK. Application of Factorial Design on the Extraction of Green Tea Leaves (Camellia sinensis L.). J App Pharm Sci, 2018; 8(04): 131-138. 